\title{
709 振り子式動吸振器による傾斜振動系の制振
}

Vibration Control of Tilted Vibration System by Pendulum Type Dynamic Vibration Absorber

$\begin{array}{ll}\text { ○正 宋 義林(金沢大) } & \text { 正 佐藤秀紀(金沢大) } \\ \text { 正 岩田 佳雄(金沢大) } & \text { 正 小松崎 俊彦(金沢大) }\end{array}$

Yilin SONG, Kanazawa University, 40-20 Kodatsuno 2 chome, Kanazawa, Ishikawa 920-8667

Hidenori SATO, Kanazawa University

Yoshio IWATA, Kanazawa University

Toshihiko KOMATSZAKI, Kanazawa University

\begin{abstract}
The vibration of a spring-mass-damper tilted vibration system with one pendulum hinged to the mass under excitation is investigated. The ratio of natural frequency of the pendulum to main system and the damping coefficient are considered as main parameters. The method of numerical calculation is used to evaluate the system response. The results of calculation show that the vibration suppression effects can be obtained at wide range of the ratio of natural frequency of the pendulum to that of main system, besides the parametrically exciting point and dynamically resonating point, but they are changed with the ratio and different tilted angles. The optimum vibration suppression effects under different ratio of nature frequency and tilted angle and correspondent damping coefficients are obtained.
\end{abstract}

Key words: Vibration control, Pendulum, Dynamic vibration absorber, Autoparametric system

本論文は振り子式動吸振器を用いた傾斜振動系の制振特 性を検討したものである. 論文では, 数值計算手法を用いて, 振り子と主系の固有振動数の比を $0.5 \sim 1$ の間に変化させ, 主系の最適制振条件を明らかにすると共に, 各傾斜角におけ る最適制振パラメータを求めた.

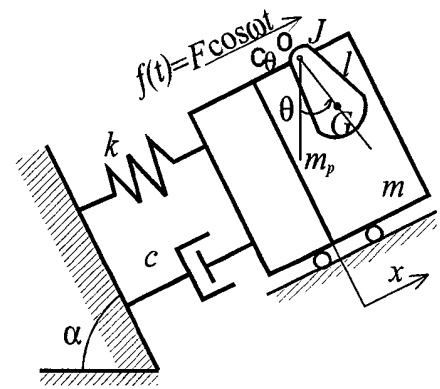

Fig.A1 Tilted vibration system with a pendulum type dynamic vibration absorber

図 A1 のような振り子式動吸振器を持つ 2 自由度傾斜振動 系の無次元運動方程式は式(A1)，(A2)で表せる.

$$
\begin{aligned}
& u^{\prime \prime}+\frac{2 \zeta}{1+\lambda} u^{\prime}+\frac{1}{1+\lambda} u+\frac{\lambda}{q(1+\lambda)}\left(\theta^{\prime \prime} \sin (\theta+\alpha)+\right. \\
& \left.+\theta^{\prime 2} \cos (\theta+\alpha)\right)=\frac{1}{(1+\lambda)} \cos z \tau \\
& \theta^{\prime \prime}+2 \zeta_{p} p \theta^{\prime}+p^{2} \sin \theta+\mu q u^{\prime \prime} \sin (\theta+\alpha)=0
\end{aligned}
$$

ここに, $u, \theta$ はそれぞれ主系と振り子の無次元変位と角変 位であり, $\lambda, p, q, \zeta_{p}$ はそれぞれ振り子と主系の質量比, 固 有振動数の比, 主系ばねの静的変位と振り子の長さの比,振 り子の減衰比である.

R.K.G 法による数值解析では, $\alpha=0^{\circ}$ の時, 当然であるが 振り子のパラメトリック励振が主系の垂直方向の制振に主 な役割を果たす.しかし, 固有振動数の比 $p$ はパラメトリッ ク励振 $(p=0.5)$ から少しずれると, 制振効果が急に悪化する. また, パラメトリック励振の狭い領域以外では, 振り子が発
振しにくくなる. 一方, $\alpha=90^{\circ}$ の時, 振り子が通常の動吸 振器に対応するため, 振り子が主系と同じ周波数で振動し, 固有振動数の比 $p$ の広い範囲で制振効果が得られやすくな る. また, $\alpha$ は $0^{\circ}, 90^{\circ}$ でない傾斜振動系の場合は, パラ メトリック励振と共振の成分が同時に振り子の振動に与え るので, 振り子の振動パタンと制振効果が傾斜角 $\alpha$, 固有振 動数の比 $p$ と振り子の減衰比 $\zeta_{p}$ に依存する. 本論文では, 傾斜角 $\alpha=0^{\circ} \sim 90^{\circ}$ において, 固有振動数の比 $p$ と振り子 の減衰比 $\zeta_{p}$ の変動による主系の最適制振を検討した.
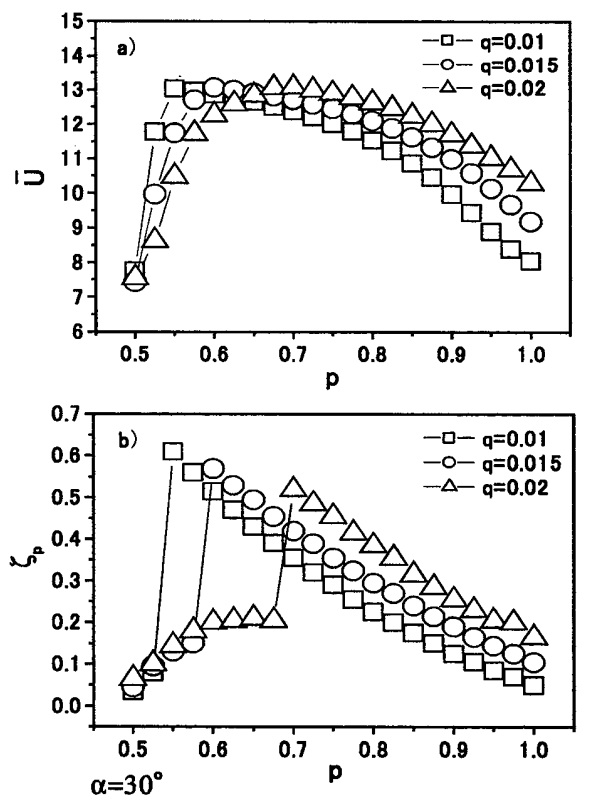

Fig.A2 The optimum vibration suppression effects of main system under different ratio of nature frequency and correspondent damping coefficients 


\section{1. はじめに}

重力軸方向に振動系に対して, パラメトリック励振を利用 した振り子を付加することにより制振を行なう手法につい て，これまで多くの報告がある ${ }^{[1-4]}$. 一方, 重力軸方向に直 角に振動する振動系に対し, 共振を利用した振り子を付加す ることにより制振を行なう手法は通常の動吸振器に対応す る. しかし，振動系がある角度で傾斜すると，振り子式動吸 振器はその傾斜振動系に適用できるかどうか, まだ解明され ていない.われわれは,これまで, その傾斜振動系について, 単振り子の場合, 振り子と主系の固有振動数の比をそれぞれ 0.5 (パラメトリック励振型)と 1 (共振型)と固定した場合の系 の制振特性と二種類の振り子式動吸振器の適用範囲を数值 的に調べた ${ }^{[5]}$

本研究では, ばね-質量 1 自由度の傾斜振動系において, 付加した振り子の固有振動数と主系の固有振動数の比を 0.5 ～1 の間に変化させ,系の制振特性の変動, 各傾斜角に招沙る 最適制振効果及びそれに対応する最適パラメータを解明す ることを目的とする.

\section{2. 運動方程式}

図 1 には傾いた 1 自由度ばね-質量系に振り子を付加した単振 り子式動吸振器系を示す. $m, k, c$ は主系の質量, ばね定数, 粘 性減衰保数, $m_{p}, c_{\theta}, J, l$ は振り子系の質量, 隇衰係数, 支点に対する慣性モーメント，支点から重心 $\mathrm{G}$ までの距離であ り， $\alpha$ は主系の運動方向と垂直方向との角度である.

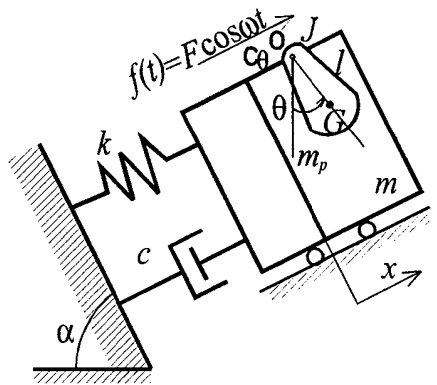

Fig. 1 Tilted vibration system with a pendulum type dynamic vibration absorber

系の運動方程式は

$$
\begin{aligned}
& \left(m+m_{p}\right) \ddot{x}+c \dot{x}+k x+m_{p} l \ddot{\theta} \sin (\theta+\alpha)+ \\
& +m_{p} l \dot{\theta}^{2} \cos (\theta+\alpha)=F \cos \omega t \\
& J \ddot{\theta}+c_{\theta} \dot{\theta}+m_{p} l g \sin \theta+m_{p} l \ddot{x} \sin (\theta+\alpha)=0
\end{aligned}
$$

ここで， $x$ は主系の変位， $\theta$ は振り子の角変位である. 方程 式(1)，(2)は無次元化すると次式になる.

$$
\begin{aligned}
& u^{\prime \prime}+\frac{2 \zeta}{1+\lambda} u^{\prime}+\frac{1}{1+\lambda} u+\frac{\lambda}{q(1+\lambda)}\left(\theta^{\prime \prime} \sin (\theta+\alpha)+\right. \\
& \left.+\theta^{\prime 2} \cos (\theta+\alpha)\right)=\frac{1}{(1+\lambda)} \cos z \tau \\
& \theta^{\prime \prime}+2 \zeta_{p} p \theta^{\prime}+p^{2} \sin \theta+\mu q u^{\prime \prime} \sin (\theta+\alpha)=0
\end{aligned}
$$

ここに

$$
2 \varepsilon=c / m, \quad \omega_{n}^{2}=k / m, \quad \lambda=m_{p} / m
$$

$$
\begin{aligned}
& \omega_{p}^{2}=m_{p} g l / J, \quad \mu=m_{p} l^{2} / J, \quad 2 \varepsilon_{p}=c_{\theta} / J \\
& x_{s t}=F / k, \quad u=x / x_{s t}, \quad p=\omega_{p} / \omega_{n} \\
& z=\omega / \omega_{n}, \quad q=x_{s t} / l, \quad \zeta=\varepsilon / \omega_{n} \\
& \zeta_{p}=\varepsilon_{p} / \omega_{p}, \quad \tau=\omega_{n} t
\end{aligned}
$$

また, 式(3), 式(4)における(') は $\tau$ による微分を表わす.

\section{3. 固有振動数の比の変化による系の制振特性}

本論文では, 傾斜振動系の傾斜角 $\alpha=0^{\circ} \sim 90^{\circ}$ において, 振 り子と主系の固有振動数の比を $0.5 \sim 1$ とすこしづつ変化させて, 振り子の振動による主系の制振特性を数値的に調べた.

固有振動数の比 $p$ における主系の最適制振及びそれに対 応する振り子の最適減衰比 $\zeta_{p}$ を求めるために, 主系の定常 振動の応答振幅 $U$ を, 共振前後の外力周波数幅に渡って二 乗平均したもの $(\bar{U})$ を最小にすることを考えた．すなわち，

$$
\bar{U}\left(\zeta_{p}, \lambda, q, z\right)=\sqrt{\frac{1}{n} \sum_{i}^{n} U_{i}^{2}} \rightarrow \min
$$

ここに, $n$ は共振周波数前後(共振点から \pm 0.15 )の計算周波 数点の数である.

計算では，式(3)，式(4)を用いて，R.K.G 法により数値的に 応答を求めた. 応答の最初の 3000 周期をカットした後の $u, \theta$ の定常振幅 $U, \Theta$ を求め, そして共振前後の外力周波数 幅に振幅の二乗平均を算出して表示した.

\section{1 傾斜角 $\alpha=0^{\circ}$ の場合}

傾斜角 $\alpha=0^{\circ}$ の場合， $p=0.5$ としたとき，パラメトリッ ク励振の条件を満たすので, それについては多くの研究が行 なわれている. しかし, 固有振動数の比 $p$ は 0.5 からずれる と, 主系の制振効果にどの影響を与えるか, また, パラメト リック励振に適用する $p$ の領域について, 理論的, 実用的に 研究する必要があると思われる。

図 2 には $\alpha=0^{\circ}, \quad p$ の值を $0.5 \sim 1$ と変動させた場合の主 系の最適制振および最適減衰を示す. 図に a)は各固有振動数 の比 $p$ における主系応答振幅の二乗平均の最小值, b)は a) に対応する振り子の最適減衰比を表わす。

図 a)の主系の最適制振効果を見ると, パラメトリック励振 の条件 $p=0.5$ では, 振り子の振動により $p$ の全領域に最適 制振が得られることがわかる. しかし, $p$ はパラメトリック 励振の条件 $(p=0.5)$ から少しずれると, 主系の制振効果が急 に悪くなることが見られた. また， $p$ の増大に従い, ある $p$ の值では, 振り子が全く振動しなく, 主系に対する制振効果 がなくなることがわかる. しかし, 振り子の振動はそれから ずっと中止を続けていくことではなく,$p=1$ に近づくと, 振り子のパラメトリック励振が再び起り, ある程度の制振効 果が得られることがわかる.

図 b)から, 図 a)の最適制振効果に対応する最適減衰比がわ かる. $p$ が 0.5 から大きくなると, $\zeta_{p}$ がともに大きくなる. これは, 外力が一定とすれば, $p$ が大きく, すなわち振り子 の固有振動数が大きくなると, 振り子の長さを短くしなけれ ばならないので, $q_{p}$ が大きくなるわけである.ここで, $q_{p}=4 q \times p^{2}, q$ は $p=0.5$ 時の值である. したがって, 主 系と振り子の定常振動を得るために, 減衰比 $\zeta_{p}$ が増大する ことになる. しかし, $p$ がパラメトリック励振点 $(p=0.5)$ か らさらにずれていくと, パラメトリック励振の条件が弱くな 
るため, 減衰が急に小さくなる現象が見られた。
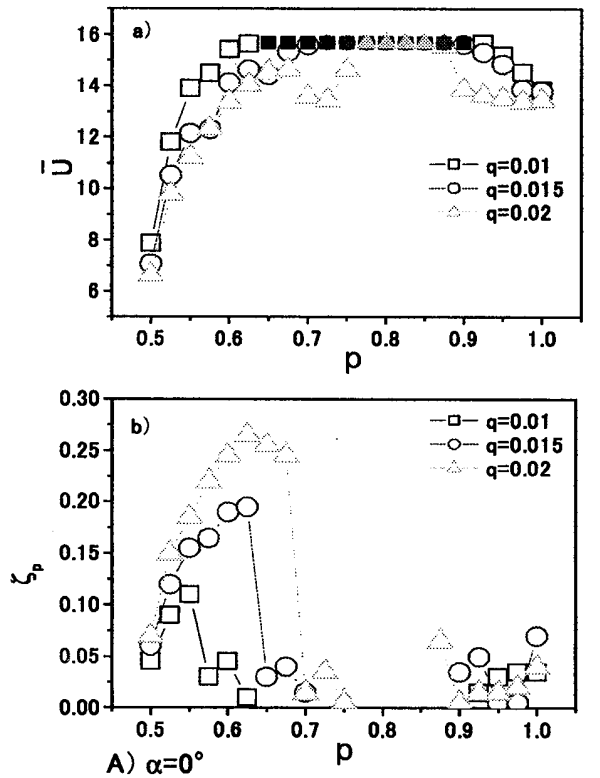

Fig. 2 The optimum vibration suppression effects of main system and correspondent damping coefficients at $\alpha=0^{\circ}$

図 3 を一例として, 各固有振動数の比 $p$ で振り子の振動パ タンを示す.ここで, $p=0.5$ 時の $q=0.02, z=0.95$ である. 図 3 から, $p=0.5$ の周辺で主系の 2 倍周期のパラメトリック 励振, $p=1$ の周辺で主系と同じ周期のパラメトリック励振 が起こることが見られた．このことから，傾斜角 $\alpha=0^{\circ}$, 固 有振動数の比 $p=1$ の付近において, 減衰があっても, 振り 子のパラメトリック励振が発生できることが確認された。
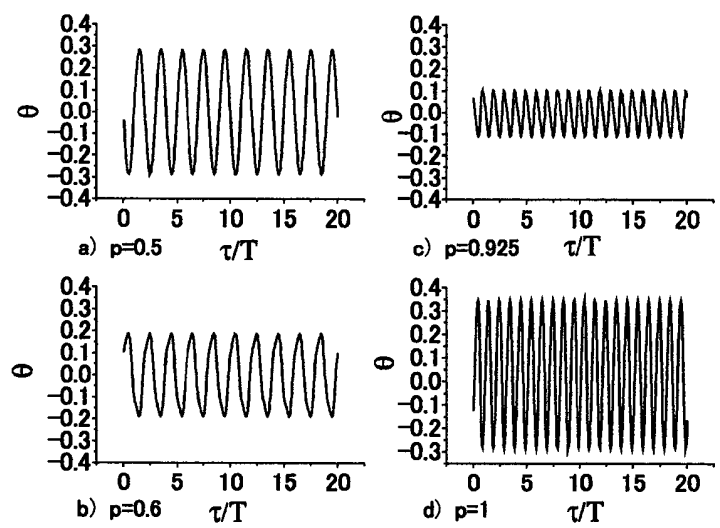

Fig. 3 The vibration patterns of pendulum under different $p$ at $q=0.02, z=0.95$

\section{2 傾斜角 $\alpha=30^{\circ}$ の場合}

図 4 に傾斜角 $\alpha=30^{\circ}$ の場合，計算した主系の最適制振及 びそれに対応する振り子の最適減衰比を示す.

図 4 を見ると,まず図 a)から固有振動数の比 $p$ の $0.5 \sim 1$ の全領域において, 振り子の発振による主系の制振をできる ことがわかる. $p=0.5$ の付近で, $\alpha=0^{\circ}$ の場合と同じよう にパラメトリック励振の条件から少しずれると, 制振効果が 急に小さくなることが見られるが，しかし，励振力の増大に したがってその減少は緩やかになることがわかる.これは励 振力の増大により振り子が発振しやすくなり, 制振効果が大 となると思われる. また, 最適制振曲線を見ると, パラメト
リック励振が終わるところはちょうと制振効果が一番小さ いところである. 一方, $p=1$ の付近で, 振り子の共振が発 生するため, 通常の動吸振器の通りにかなりの制振効果があ ることが見られた. 制振曲線の全体を考察すると, 系の最適 制振点はパラメトリック励振が起こる $p=0.5$ のところであ ることがわかる.

また, 図 b)の振り子の最適減衰比を見ると, パラメトリッ ク励振点の $p=0.5$ では, 減衰比 $\zeta_{p}$ の值が一番小さい. その 後, $p$ の増大に従い $\zeta_{p}$ もやや増大する. しかし, ある $p$ の 值では, $\zeta_{p}$ が急に大きくなる跳び現象が出てくる. また, この $\zeta_{p}$ に対応する主系の最適制振はちょうど一番小さいと ころである. したがって, この $p$ は振り子のパラメトリック 励振による振動からダイナミック共振による振動を変換す る点であることが考えられる．その後の $\zeta_{p}$ は $p$ の増大に従 い除除に小さくなる.
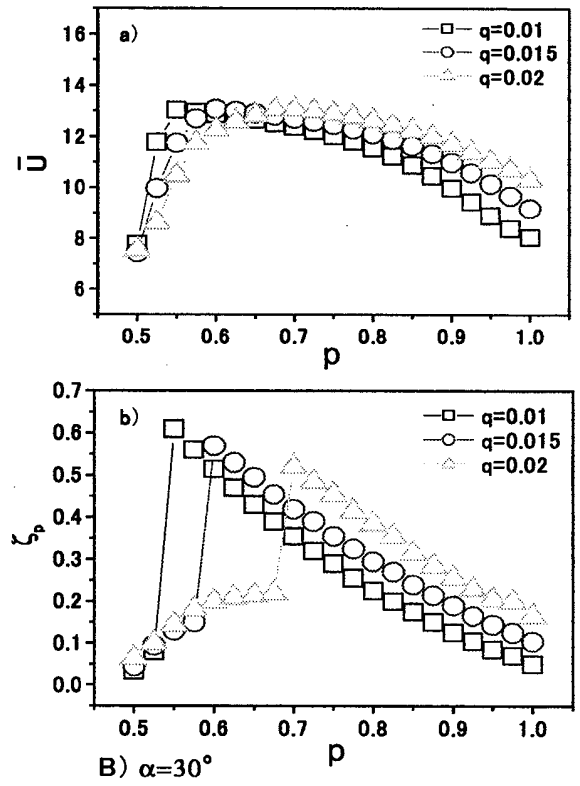

Fig. 4 The optimum vibration suppression effects of main system and correspondent damping coefficients at $\alpha=30^{\circ}$

図 5 に減衰比 $\zeta_{p}$ の跳び現象が起こる $q=0.015$, $p=0.575,0.6, \zeta_{p}=0.15,0.57$ の時の振り子の振動パタン を示す.また, $q=0.015, p=0.6$ では, 各減衰比 $\zeta_{p}$ にお ける主系の応答を図 6 に示す.

図 5 より, $q=0.015$ に扔いて, 振り子の振動は $p=0.575$, $\zeta_{p}=0.15$ で, パラメトリック励振, $p=0.6, \zeta_{p}=0.57$ で, ダ イナミック共振であることがわかる.また, $q=0.01$ と $q=0.02$ の場合は $q=0.015$ と同じであるので, 図 4 の減衰比 $\zeta_{p}$ の跳 び現象は, 振り子の振動パタンの変化により起こることが確 認された.

図 6 に $p=0.6, q=0.015$ では, 主系の制振効果は振り子の減 衰比 $\zeta_{p}$ により変動する傾向を示す. $\zeta_{p}<0.155$ 時, 振り子 と主系が同時に非定常振動が起こる. また, $\zeta_{p}=0.155$ 時, 振り子の定常的なパラメトリック励振振動になるため, かな りな制振効果が得られる. しかし， $\zeta_{p}$ が大きくするに連れ て, パラメトリック励振が弱くなり, 制振効果が小さくなる. $\zeta_{p}=0.205$ では, 制振効果の最小值にいたる. その後, ダイ ナミック共振の成分が強く, 振り子に支配する振動はパラメ トリック励振から共振に変わり, $\zeta_{p}=0.57$ では, 振り子の共 振により, 最大制振効果が求められる. 
図 7 に図 6 の制振曲線の a, b, c, d 各位置の振り子の振 動パタンを示す. 図 7 から, 減衰比 $\zeta_{p}$ の増大にしたがって, 振り子の振動はパラメトリック励振から共振にだんだんに 変わっていき, 振幅はだんだん小さくなることがわかる.
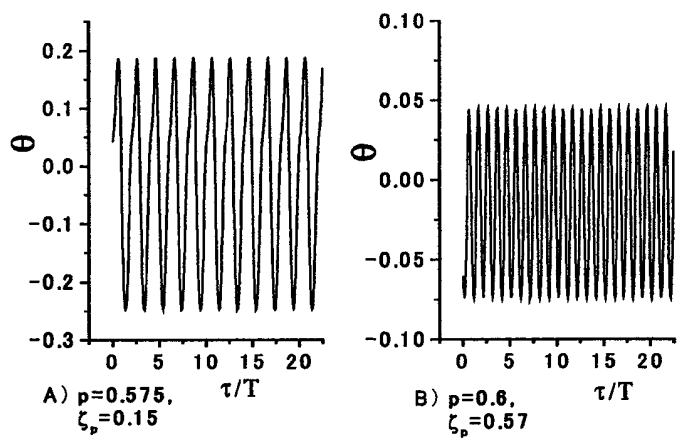

Fig. 5 The vibration patterns of pendulum under different $p$ and $\zeta_{p}$ at $q=0.015, z=0.96$

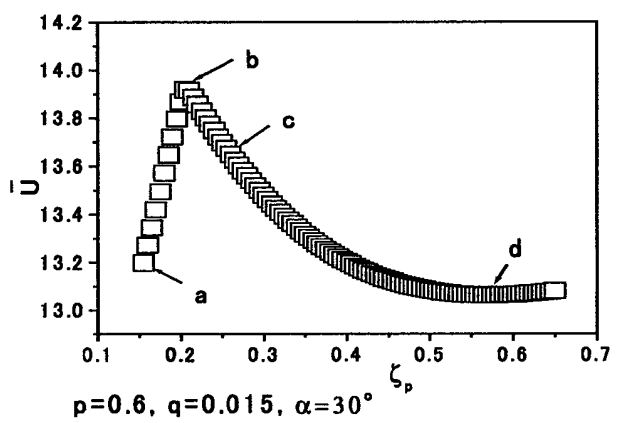

Fig. 6 The vibration suppression effects of main system under different $\zeta_{p}$ at $p=0.6, q=0.015$ and $\alpha=30^{\circ}$
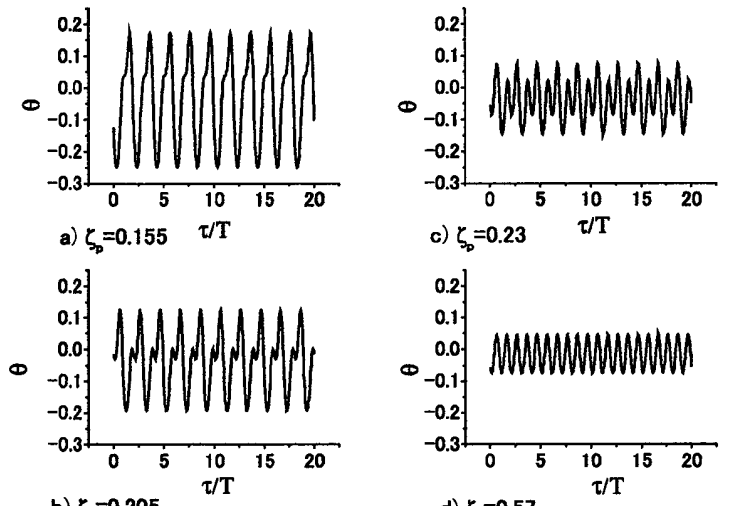

b) $\zeta_{p}=0.205$

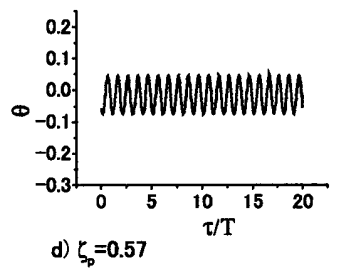

Fig. 7 The vibration patterns of pendulum under different $\zeta_{p}$ at $p=0.6, q=0.015, z=0.96$ and $\alpha=30^{\circ}$

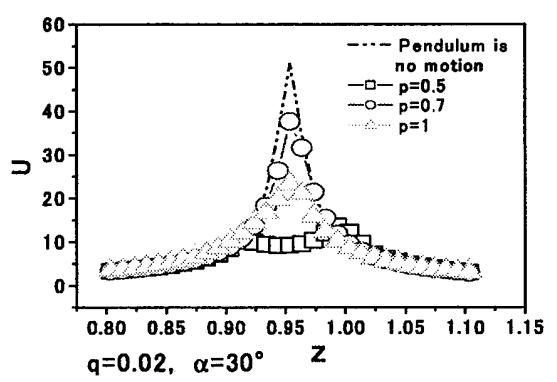

Fig. 8 The optimum vibration suppression effects of main system under different $p$ at $\alpha=30^{\circ}$
図 8 に最適制振の条件において $, p=0.5,0.7,1$ のときの 主系の応答曲線を示す. 図により, 異なる $p$ では, 振り子の 振動パタンが違うが, 応答曲線の形には大きい違いがなく, 基本的に振り子が系の共振点の付近で発振することがわか る.

\section{3 傾斜角 $\alpha=60^{\circ}$ の場合}

図 9 に傾斜角 $\alpha=60^{\circ}$ の場合, 計算した主系の最適制振及 びそれに対応する振り子の最適減衰比 $\zeta_{p}$ を示す.
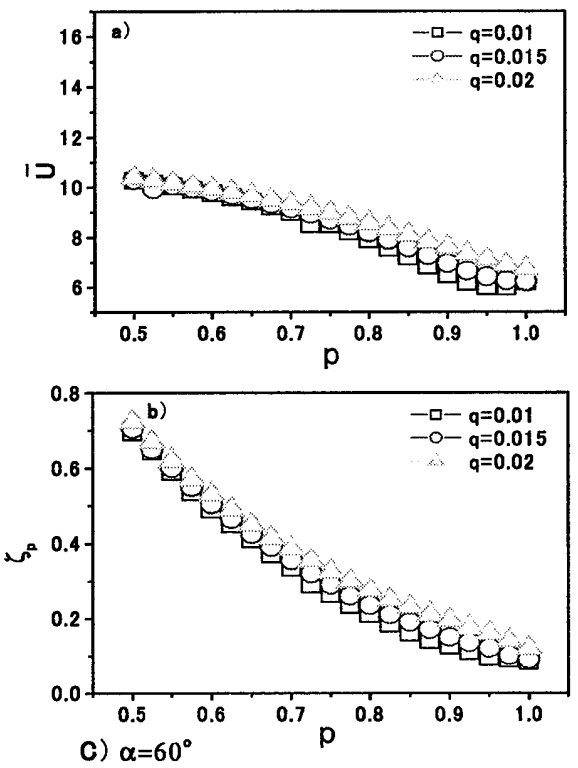

Fig. 9 The optimum vibration suppression effects of main system and correspondent damping coefficients at $\alpha=60^{\circ}$

図 9 を図 4 と比べると, 傾斜角 $\alpha=60^{\circ}$ の場合は主系の最 適制振に対して, パラメトリック励振の影響は小さくなるこ とがわかる. $p=0.5$ の付近では, 振り子のパラメトリック励 振が起こるが, 最適制振が得られにくくなる. 一方, 共振振 動が, $p$ における最適制振が得られやすくなる. また, 各 $p$ において, 最適制振効果は図 4 のような激しい変化を見らず, 緩やかに変動することがわかる.

図 b)の減衰比 $\zeta_{p}$ に関するグラフを見ると,傾斜角 $\alpha=30^{\circ}$ の場合とは違って, 跳び現象が見られなかった.これは傾斜 角が大きくなると, パラメトリック励振の成分が小さく, 共 振振動の成分が大きくなるので, $p=0.5$ 付近でも, 主系の最 適制振に支配する振り子の振動は共振振動であると考えら れる.

\section{4 傾斜角 $\alpha=90^{\circ}$ の場合}

図 10 に傾斜角 $\alpha=90^{\circ}$ の場合, 計算した主系の最適制振及 びそれに対応する振り子の最適減衰比 $\zeta_{p}$ を示す.

図 a)を見ると, $p$ の全領域に良い制振効果が得られること がわかる. 式(4)の振り子の運動方程式において, 振り子が小 振幅で振動することを仮定すれば，式(4)は式(6)になる.

$$
\theta^{\prime \prime}+2 \zeta_{p} p \theta^{\prime}+p^{2} \theta=-\mu q u^{\prime \prime}
$$

したがって, そのときの振り子はパラメトッリク励振系では なく, 単純な強制振動系である. また, 振り子の振動は主系 の振動加速度に依存するので, 通常の動吸振器に対応すると 考えられる. したがって, $p=1$ の付近では, 最適な制振効 
果が得られ, 共振点と離れるに連れて, 制振効果がやや小さ くなっていく傾向が見られる. 傾斜角 $\alpha$ の全体を見ると， $\alpha$ $=90^{\circ}$ では, 他の傾斜角に比べて, 制振効果が一番いいと言 える.

また，図 b)を見ると，その場合はパラメトリック励振の成 分がなくなるため, 最適減衰比 $\zeta_{p}$ の跳び現象が出てこなく, $p=0.5$ 時の $\zeta_{p}$ が一番大きい, その後 $p$ の増大に従い徐々に 小さくなることがわかる.
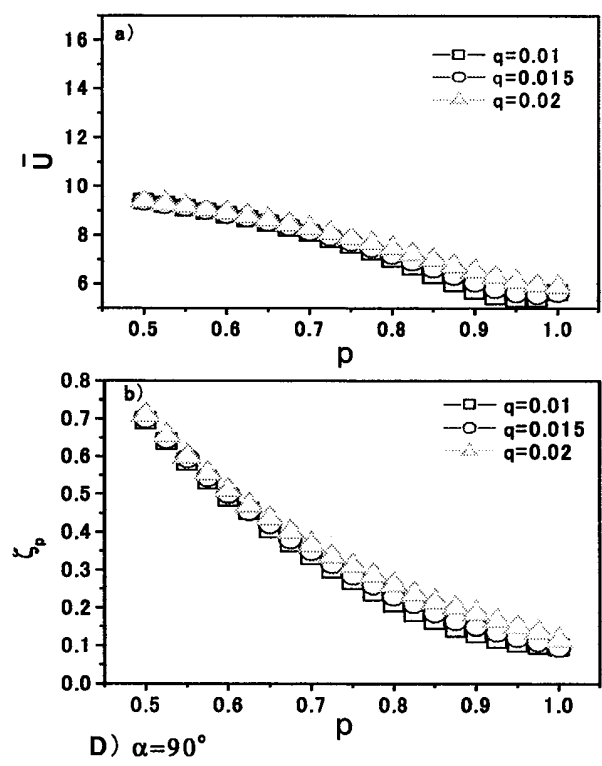

Fig. 10 The optimum vibration suppression effects of main system and correspondent damping coefficients at $\alpha=90^{\circ}$

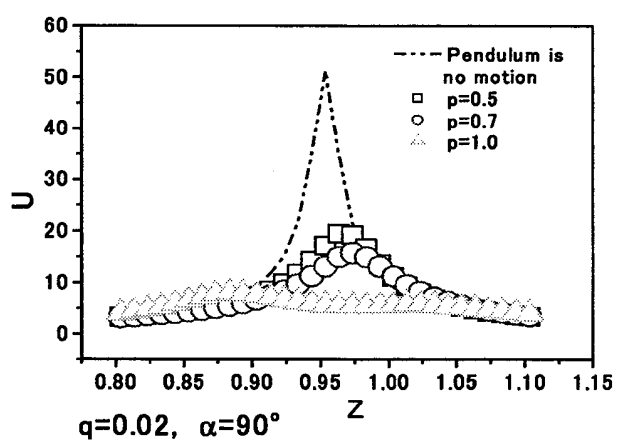

Fig. 8 The optimum vibration suppression effects of main system under different $p$ at $\alpha=90^{\circ}$

図 11 に最適な制振条件において, $p=0.5,0.7,1.0$ のとき の主系の忘答曲線を示す. その時の振り子が主系と同じ周波 数で振動し, 通常の動吸振器のような 2 自由度系になってい る. $p=0.5,0.7$ では, 振り子の共振振動によるかなり制振 効果があるが, 振り子と主系の固有振動数がずれるため, $p=1.0$ 時のような最適制振効果が得られなかった.また, 図 8 と比べて, 傾斜角による最適な制振条件が変わることがわか る.

\section{5 全傾斜角の制振}

図 12 に以上の各傾斜角で求めた主系応答の最小値 $\bar{U}$ を示 す. $\bar{U}$ の最小値を見ると，傾斜角が小さい時はパラメトリ ック励振型振り子が有効, 大きい場合は共振型振り子が有効
であることがわかる. 具体的に言うと, 傾斜振動系の傾斜角 は垂直位置から $30^{\circ}$ 以内であれば, パラメトリック励振型振 り子式動吸振器を選び, 傾斜角は $30^{\circ}$ を超えれば, 共振型振 り子式動吸振器を選ぶことにより, 傾斜振動系についての制 振を向上させることが可能である. また，図 12 から，qの 増大に従いパラメトリック励振型振り子の適用範囲は広く なり，共振型振り子の適用範囲は狭くなることがわかる。

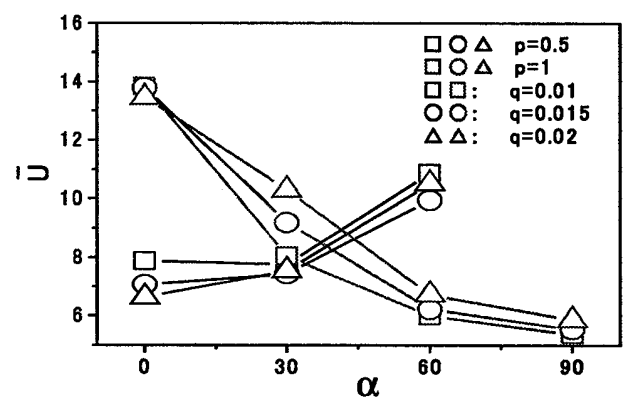

Fig. 12 The minimum value of response of main system under different angle $\alpha$

\section{4. 結 言}

以上，本研究で得られた結果を要約すると，

1) 1 自由度のばね一質量傾斜振動系において, 振り子式 動吸振器を付ける場合の主系の制振特性を, 数值的に明らか にし, 各傾斜角では固有振動数の比の変動により最適制振効 果及びそれに対応する最適減衰比を求めた.

2) $p=0.5$ 付近の振り子のパラメトリック励振では, 固有 振動数の比が少しずれると, 主系の制振に大きい影響を与え るのに対し, $p=1.0$ 付近の振り子の共振では, 固有振動数の 比の変動は主系の制振に敏感に影響しなくなり, $p$ のある範 国に最適值が得られやすくなる．また，主系の最適制振に対 応する最適減衰比に跳び現象が見られた。これは振り子の振 動パタンが, パラメトリック励振から共振型へ変換すること により生じたものと考えられる.

3) 傾斜振動系の傾斜角は垂直位置から $30^{\circ}$ 以内であれば, パラメトリック励振型振り子式動吸振器 $(p=0.5)$ が有効であ り, 傾斜角が $30^{\circ}$ を超えれば, 共振型振り子式動吸振器 $(p=1.0)$ が有効であることが確認された.

\section{文 献}

(1) Haxton, R.S. and Barr, A.D.S, The autoparametric vibration absorber, Trans. ASME, J. Eng. Ind.94 (1972), 119-125.

(2) Bajaj, A,K, Chang, S.I. and Johnson, J.M., Amplitude modulated dynamics of a resonantly excited autoparametric two degree-of-freedom system, Nonlinear Dynamics. 5 (1994), 433-457.

(3)宋義林, 佐藤秀紀, 岩田佳雄, 小松崎俊彦, 振り子のパラ メトリック励振を利用した動吸振器采の応答, 機論, 67-611, C(2001), 2763-2769.

(4) Song, Y., Sato, H., Iwata, Y. and Komatsuzaki, T., The response of dynamic vibration absorber system with a parametrically excited pendulum, J. Sound Vib 259(2003),747-759

(5) 宋義林, 佐藤秀紀, 岩田佳雄, 小松崎俊彦, 傾いた振り 子式動吸振器系の応答, 第 2 回ダンピングシンポジウム講 演論文集(2002), 331-336. 